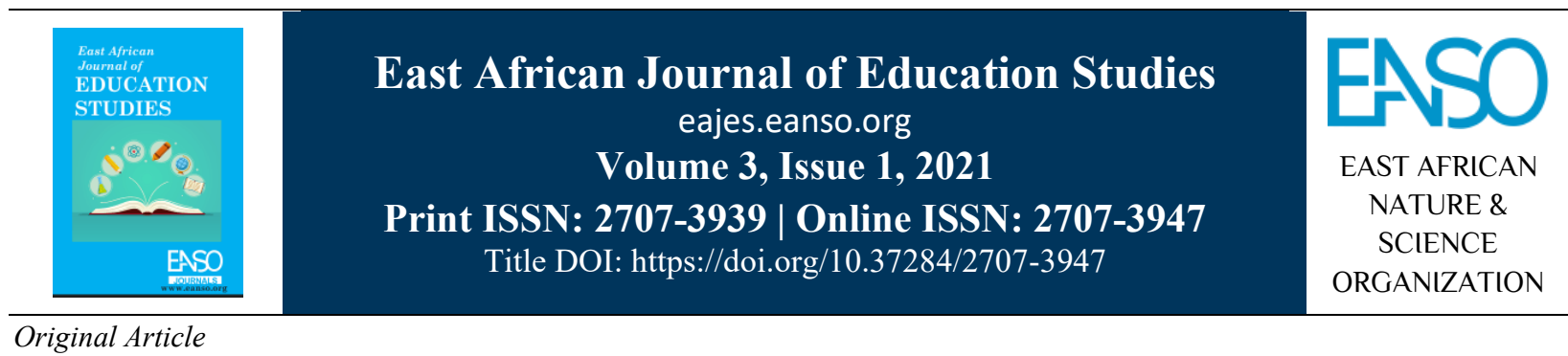

\title{
Effectiveness of Non-Governmental Organisations' Activities in Basic Education in Supporting School Dropped Out Girls in Shinyanga Region, Tanzania
}

\author{
Ezekiel Kassanga ${ }^{* 1}$ \& Chrispina Lekule ${ }^{1}$ \\ ${ }^{1}$ St. Augustine University of Tanzania, P. O. Box 307, Mwanza, Tanzania. \\ *ORCID: https://orcid.org/0000-0002-4177-6388; Author for Correspondence Email: brkassanga52@gmail.com.
}

Article DOI: https://doi.org/10.37284/eajes.3.1.269

\section{Date Published: ABSTRACT}

04 February 2021 This study examined NGOs' effectiveness in supporting teenage mothers who dropped out of schools due to pregnancy to accomplish basic education out of

Keywords: the public school system in Tanzania using Shinyanga region as a case study.

Basic Education,

Non-Governmental

Organization (NGOs),

Pregnant Schoolgirls,

Teenage Mothers.
10 NGOs, 20 teenage mothers who are supported by NGOs and 20 parents/guardians of the supported teenage mothers. For the purpose of investigation; interviews, questionnaires and documents review were used as instruments. The results of this study indicated that most of the NGOs activities' such as sensitisation, sponsorship, provision of learning materials and running of learning centres, among others are generally ineffective in enabling the ever-increasing teenage mothers to accomplish basic education out of public school system. Its consequence is the fact that most teenage mothers are left under the plight of ignorance. Thus, recommendations are made for the government, NGOs, parents and community members to admit the fact that pregnancy among school girls is not a crime against morality but a tragedy for girls hence deliberate remedies should be done for enabling them to access basic education after delivery because educating a girl is to educate the nation.

\section{APA CITATION}

Kassanga, E., \& Lekule, C. (2021). Effectiveness of Non-Governmental Organisations' Activities in Basic Education in Supporting School Dropped Out Girls in Shinyanga Region, Tanzania. East African Journal of Education Studies, 3(1), 14-25. https://doi.org/10.37284/eajes.3.1.269.

\section{CHICAGO CITATION}

Kassanga, Ezekiel, and Chrispina Lekule. 2021. "Effectiveness of Non-Governmental Organisations' Activities in Basic Education in Supporting School Dropped Out Girls in Shinyanga Region, Tanzania". East African Journal of Education Studies 3 (1), 14-25. https://doi.org/10.37284/eajes.3.1.269. 


\section{HARVARD CITATION}

Kassanga, E. and Lekule, C. (2021) "Effectiveness of Non-Governmental Organisations' Activities in Basic Education in Supporting School Dropped Out Girls in Shinyanga Region, Tanzania”, East African Journal of Education Studies, 3(1), pp. 14-25. doi: 10.37284/eajes.3.1.269.

\section{IEEE CITATION}

E. Kassanga, and C. Lekule, "Effectiveness of Non-Governmental Organisations' Activities in Basic Education in Supporting School Dropped Out Girls in Shinyanga Region, Tanzania”, EAJES, vol. 3, no. 1, pp. 14-25, Feb. 2021.

\section{MLA CITATION}

Kassanga, Ezekiel, and Chrispina Lekule. "Effectiveness of Non-Governmental Organisations' Activities in Basic Education in Supporting School Dropped Out Girls in Shinyanga Region, Tanzania”. East African Journal of Education Studies, Vol. 3, no. 1, Feb. 2021, pp. 14-25, doi:10.37284/eajes.3.1.269.

\section{INTRODUCTION}

Activities of NGOs in providing basic education to vulnerable children including pregnant students and teenage mothers are well known across the world. Approaches for such support may differ from one NGO to another, but the legitimacy remains the fact that vulnerability is a daily reality for a large number of female students across the world. For instance, the 2014 World Health Organization's report on the girl child's vulnerability depicts about $18 \%$ of allgirl children in the world have been sexually abused during their childhood (WHO, 2014).

The need for NGOs as help-giving organisations was realised by the United Nations Charter (Chapter 10, Article 71) of 1945, whereby the resolution recognises the existence and operation of NGOs. The resolution marked an evolution of different categories of NGOs including those that deal with education support, especially for the marginalised children with the same consideration to teenage mothers. Several NGOs were formed including UNICEF, which was established in December 1946 for safeguarding child right to education among other rights. Since then, many other NGOs that deal with education support to vulnerable children have been established in almost all continents of the world (Clark, 1996). A number of reports show that NGOs across continents and countries have eventually strived to support education for all children irrespective of their gender, race or culture (Kiseu, 2012; Shivji, 2004; UNICEF, 2003). Rose (2009) recognised NGOs activities in education service delivery as a function characterised by varied approaches depending on the context of operation and societal needs. Such approaches may include advocacy on government fulfilment of its commitment to education for all and direct assistance to children who in one way or another have been excluded from the public schooling system. With the same motive, other NGOs have focused on supporting the governments in improving equitable access and provision of education.

A number of records and reports assert that in Africa, NGOs activities are well-known in supporting vulnerable children and teenage mothers in particular to access education (Jivan, 2010; Kisanji, 2009; Omwancha, 2012; Tripp, 2000). For example, in Nigeria, the involvement of NGOs in raising voices for women and girls education is so popular, especially in influencing equality and equity in education policy. Being a country characterised by a dense population and strong traditional values in most of its provinces. The efforts of NGOs like UNICEF have contributed to the development of the Strategy for the Acceleration of Girls' Education (SAGE) in the country by the end of 2004 (Akunga, 2008).

In Tanzania, the role of NGOs in supplementing government efforts in the provision of education was realised even before the attainment of independence in 1961. According to Kiondo, Wallevik and Lange (2000), there were about 85 NGO-sponsored schools in Tanzania by 1984 . With a special focus on education support to teenage mothers who are expelled from public schools due to pregnancy, UMATI (Chama cha Uzazi na Malezi Bora Tanzania) which is one of the oldest NGOs in Tanzania, has been involved in helping teenage mothers since the 1980s. The organisation has established several education centres countrywide with the first centre at Temeke District in 1986 (Mushi, 2009). Swainson et al. (1998) assert that one of the aims of UMATI education programme 
was to support teenage mothers to complete basic education and demonstrate to policymakers that such girls could complete their education.

Currently, the Tanzanian Education and Training Policy (2014) recognises and stresses the participation of NGOs in the development of the education sector. NGOs have been identified as one of the key stakeholders in the provision of education in the country with much focus on the enhancement of gender equality in education and training. In response, among others, Equip Tanzania NGO has allocated most of its resources in supplementing government efforts in providing quality and equitable education in the country. By December 2016 the NGO had supported schools in Tabora, Simiyu, Dodoma, Shinyanga, Kigoma, Mara, and Lindi regions to adopt the more gender-responsive approaches in enhancing access of girl pupils to primary schools by addressing issues of genderbased violence and menstrual hygiene management for girls (EQUIP, 2017). Likewise, HAKIELIMU and other influential NGOs like Policy Forum, TGNP Mtandao and TAWLA have advocated and pushed for gender parity and re-entry of pregnant girl students to a level that in 2009 the government of Tanzania issued the guidelines on how to enable pregnant school girls to continue with their studies. The guideline was therefore welcomed as a foundation towards the re-entry of pregnant schoolgirls in Tanzania's mainland though it has never been implemented.

For moral reasons, Tanzanian girl students who get pregnant while in primary and secondary schools are forbidden from returning to public schools (Hombo \& Haule, 2017). Instead, the Tanzanian government urged devoted NGOs to support teenage mothers through Alternative Education Pathways (AEPs). The devoted NGOs have been argued to focus on the establishment of facilities so as create chances and opportunities for teenage mothers to accomplish education out of the public school system.

A number of NGOs have taken strategic steps to ensure that teenage mothers secure a second chance to access and complete basic education out of the public school system. However, given the growing number of girl children who drop out of school due to pregnancy and the total withdrawal of the government from the commitment of re-admitting them in the publicly-funded schools, it was questionable as to how much can the involved NGOs do, and how effective is their support. Hence, given the importance of educating girls and the repercussions of failing to do so, investigating the effectiveness of NGOs activities in supporting Tanzanian teenage mothers is necessary. In the Shinyanga region, where this study was conducted, local and international NGOs like UNESCO, Save Children, and Agape Foundation have specifically engaged in supporting teenage mothers. Although the presence of the mentioned NGOs in the region is well known, the kind of activities done and their effectiveness remained unclear because of the shortage of prior research despite the higher prevalence of child marriages (about 59\%) which is a key driver to teenage pregnancy (URT, 2017). It has been argued that, if you educate a girl, you educate a village/country and that failure to educate girls, will have a deleterious social impact on both the individual girls and the nation at large. Hence, the lack of knowledge about NGOs activities and their effectiveness in supporting teenage mothers was a problem that must be studied. Hence, it is from this standpoint that this study was carried out in the Shinyanga region in Tanzania. So, the purpose of this study was to assess the effectiveness of NGOs activities in supporting teenage mothers to accomplish basic education out of the public school system. Specifically, this study aimed at;

(a) Exploring the kind of basic education activities that are carried out by NGOs in support of teenage mothers

(b)Finding out how effective the NGOs have been in supporting teenage mothers to accomplish basic education out of the public school system.

(c) Examining the ability of NGOs in maintaining continuity of activities that supports teenage mothers to accomplish basic education out of the public school system. 


\section{LITERATURE REVIEW}

\section{NGOs' Basic Education Support for Teenage mothers}

NGOs' activities providing educational support to teenage mothers are mainly determined by the mission, objectives and financial capacity of the particular NGO. In this regard, approaches, types and scope of activities do differ from one NGO to another. Rose (2009) identified three activities known as advocacy, support to the government in upholding equality, and direct delivery of education. In this regard, advocacy stresses putting pressure on the governments to fulfil their duty to providing education to all who deserve it including allowing the re-entry of female students who gets pregnant while schooling. For instance, UNESCO (2015) reported having participated in the development of the Tanzanian guideline for enabling pregnant school girls to continue with their studies which were issued by the Ministry of Education and Vocational Training (MOEVT) in 2009. The guideline was expected to stop further expulsion of pregnant students and assist the expelled ones to return to public schools.

According to Mbugua (2013), various NGOs both in and outside Africa have strived and devoted to the direct provision of education to pregnant students where the government system has excluded them. Likewise, Mushi (2009) identifies UMATI as a remarkable NGO which has succeeded in the provision of basic education support by operating education centres for female students who dropped out of schools due to pregnancy since 1984. The first centre which is known as Dar es salaam Youth Centre was opened in Temeke district in 1984 with other many centres that were opened in Iringa, Mbeya and other regions of Tanzania. Issah (2012) depicts fundraising and partnership as other activities are done by local African NGOs in supporting teenage mothers' basic education. The author identifies NGOs like CRS in Ghana that has engaged in fundraising and used the raised fund in supporting projects that aimed at increasing reenrolment of girls and teenage mothers as well. CRS reported having partnered with the United States Agency for International Development (USAID) in the implementation of the project known as the Education Support Program (ESP) in Ghana.
According to Mushi (2009), other NGOs have focused on offering sensitisation and counselling services that create awareness and psycho-support in enabling teenage mothers to accomplish basic education out of the public school system. Such NGOs includes Care International which has been implementing the Basic Education Fellowship (BEF) programme through capacitating several local NGOs like Elimu na Malezi ya Vijana (EMAU) to design, implement, manage and control their own education initiatives for improving access to quality education for children and adults in Tanzania.

Sponsoring of schooling through alternative pathways has been reported as another NGOs' activity in supporting teenage mothers. For instance, the findings from SRHRA and Rutgers (2016) revealed that some of the teenage mothers in Tanzania had joined private schools and or institutes of adult education after being expelled from public schools. Niskanen (2012) asserted that the Tanzanian Swedish NGO known as Karibu Tanzania has been sponsoring parent students schooling at the Institute of Adult Education Center in Njombe. Likewise, Georgen (2009) stressed the work of Edukaid in Mitindani Mtwara, where supports to poor girls were given through the provision of fees and uniforms. In addition to that, if supported girls became pregnant, the same NGO also supports with school fees for a girl to return to private schools.

In its report on "Providing Alternative Learning for Adolescent Mothers", UNESCO (2015) identified economic capacity development as a means of capacitating teenage mothers to raise funds for covering costs in non-formal secondary education and evening classes. The project was implemented in Shinyanga rural, Kahama and Msalala districts where about 149 teenage mothers were supported. Moreover, HEART (2015) pinpointed accelerated learning as the NGOs activity that supports teenage mothers who fail to re-enrol in public schools in Kenya. Being implemented as a special programme by the NGO known as HOPE for Teenage Mothers in Mukuru kwa Ruben slums in Kenya, identified girls are taught under special sessions before being registered for national examination as other students. 
Efficiency of NGOs Activities in Providing Basic Education Support to Teenage Mothers

The legal framework in Tanzania provides NGOs with responsibilities and grounds to conduct their activities and programs in providing basic education support to teenage mothers. The efficiency of NGOs involvement is not well achieved. For instance, a report on Tanzania's Sexual and Reproductive Health and Rights (2016) shows that NGOs' advocacy for the re-entry of pregnant school girls is done at different levels of decision making and policy review. However, the decision for policy change remains in the hands of the policymakers regardless of the increased demand for creating the chance for re-enrollment of teenage mothers. This is evident in the recent policy practices that restrict reentry in public schools in the country.

UNESCO (2015) reported the success of NGOs in influencing teenage mothers to prepare themselves for re-entry in non-formal secondary education. Its report depicts that about 149 who graduated in vocational training under its support in the Shinyanga region in August 2015 were preparing to enroll in non-formal secondary education in January 2016. Regardless of that success, its effectiveness is uncertain due to a lack of evidence of the said girls enrolled in non-formal education and if they all managed to complete school up to form four. Likewise, the SRHRA and Rutgers report (2016) showed that only a small number of pregnant students return to schools after delivery. One of the reasons as per SRHRA and Rutgers finding is the lack of officiated guidelines for implementation of re-entry in education and training policy. With that, NGOs lack a documented guideline to follow in the implementation of their activities for basic education support; hence they underperform. On the other side, Mbugua (2013) asserted that the most vulnerable pregnant schoolgirls are found in rural areas where NGOs programs are not so common.

According to Rose (2009), obtaining an overall impression of the level of effectiveness of NGOs activities is problematic. Most NGOs reports are not generally collected by the ministries of education or by household surveys. In this regard, the evaluation of NGOs' activities in supporting teenage mothers becomes difficult due to the general lack of accurate baseline data. The tendency has consequently resulted in poor performance among many NGOs due to a lack of recommendations for improvement. Winthrop and King (2015) assert that many of the NGOs provide insufficient support across the world. Condition like this is so common in Tanzania where the works of NGOs in supporting teenage mothers are not well coordinated.

\section{Sustainability of NGOs Activities in Basic Education Support to Teenage Mothers}

The state of NGOs' sustainability in the provision of basic education to teenage mothers is subjected to a number of challenges. According to Maluli and Bali (2014), as cited by Lwiza (2014), re-entry support by NGOs and other stakeholders is challenged even by some of the school administrators and staff in Tanzania. It is challenged with the fear that NGOs support may catalyse adolescent pregnancy and motherhood in Tanzanian schools that would set a bad example and spoil other female students. Challenges like these create some sort of dilemma and confusion to NGOs, especially in planning towards appropriate and sustainable education support to teenage mothers.

Similarly, some of the religious leaders are against the NGOs interventions. For example, the Catholic Archbishop of Songea criticised NGOs advocacy for re-entry in public schools by terming it as a "foreign idea that wants us to defy our culture" (Aglionby, 2017). In addition to that, Sik (2015) points out the uncertain sustainability of NGOs activities because of the extreme use of a traditional top-down approach in activities implementation. The traditional approach does not create much impact but short-lived because most of the NGOs tend to focus on the immediate barriers that girl children encountered rather than exploring the key issue. This situation is evident in the Tanzanian context where most of the NGOs do not involve the beneficiaries in designing the interventions; hence most of their activities do lack community ownership.

\section{METHODOLOGY}

This research was conducted from 2018 to 2019 under the department of Education Foundations, Faculty of Education at St. Augustine University of Tanzania in partial fulfilment of the requirements 
for the award of master degree in Education Management and Planning (MEMP). For the purposes of investigation, qualitative and quantitative approaches were combined as the research design. The study was composed of 50 respondents from $10 \mathrm{NGOs,} 20$ teenage mothers who have been supported by NGOs, and 20 parents/guardians of the supported teenage mothers. In the collection and creation of qualitative information, in-depth interviews were directed to the teenage mothers and their parents/guardians who were assured for complete anonymity in the data processing. The aim of the interviews was to examine the effectiveness of NGOs activities with regards to the achievement of teenage mothers in completing basic education out of the public school system. The interviews were recorded through notetaking and audio recorder then coded thematically, transcribed, analysed and presented in narrative form using descriptions and quotations.

On the other side, quantitative data were collected by the use of questionnaires and document reviews. Questionnaires were administered to 10 leaders of NGOs for the purpose of identifying different activities carried out in support of teenage mothers, a number of helped teenage mothers as well as strategies of NGOs in maintaining support to teenage mothers. Quantitative data analysis was done through the Statistical Package for Social Science software (SPSS version 20). The results from quantitative data are presented in percentages and frequencies by using descriptive statistics and frequency distribution tables and graphs that summarised data on the close-ended items. Likewise, document review was done purposefully for corroborating the level of support provided to teenage mothers, strategies and practice of NGOs activities in marinating their support to teenage mothers. On the other side, the purposive technique was used as a major guide in the selection of the informers because of their relationship with the subject matter of the study. For instance, on the side of NGOs, purposive sampling was essential in giving a precise list of NGOs that are particularly dealing with the provision of basic education support as their thematic area.

\section{RESULTS AND DISCUSSION}

\section{Types of NGOs Activities in Provision of Basic Education Support to Teenage Mothers}

The findings revealed that almost $100 \%$ of the studied NGOs have a combination of several activities implemented for supporting teenage mothers to access basic education out of the public school system. Researchers grouped activities mentioned by informants into major categories such as paying school fees, provision of learning materials as well as sensitising and counselling teenage mothers, community, guardians and parents about alternative pathways through which teenage mothers can access basic education out of the public school system. Other activities include running learning centres that enrol teenage mothers, searching for local and international sponsors, partnering with parents/guardians and linking the girls with other supporting NGOs and schools that enrol teenage mothers. Below is the figure that presents a list of major activities implemented by NGOs in the provision of basic education to teenage mothers.

Table 1: Types of NGOs Activities in Basic Education Support to Teenage Mothers

\begin{tabular}{lll}
\hline Type of activities & NGOs involved & NGOs not involved \\
\hline $\begin{array}{l}\text { Paying school fees } \\
\text { Providing learning materials }\end{array}$ & $3(30 \%)$ & $7(90 \%)$ \\
$\begin{array}{l}\text { Sensitising and counselling teenage mothers about } \\
\text { alternative pathways }\end{array}$ & $4(40 \%)$ & $6(60 \%)$ \\
$\begin{array}{l}\text { Sensitising the community, guardians and parents to support } \\
\text { teenage mothers through alternative pathways }\end{array}$ & $8(80 \%)$ & $2(20 \%)$ \\
$\begin{array}{l}\text { Running a learning centre that enrols teenage mothers } \\
\text { Searching for local and international sponsors for teenage } \\
\text { mothers. }\end{array}$ & $1(10 \%)$ & $9(90 \%)$ \\
\hline
\end{tabular}




\begin{tabular}{lll}
\hline Type of activities & NGOs involved & NGOs not involved \\
\hline $\begin{array}{l}\text { Partnering with parents/guardians in financing teenage } \\
\text { mothers' education }\end{array}$ & $5(50 \%)$ & $5(50 \%)$ \\
$\begin{array}{l}\text { Linking teenage mothers with other supporting NGOs } \\
\text { Linking girls with schools/institutions that enrols teenage } \\
\text { mothers }\end{array}$ & $9(90 \%)$ & $1(10 \%)$ \\
\hline
\end{tabular}

Table 1 shows that $30 \%$ of the NGOs pay school fees in institutions where teenage mothers have been enrolled. The findings showed that such financial assistance is given to teenage mothers who have no financial support from elsewhere due to factors such as poverty or stigma. A similar activity was also reported by Niskanen (2012) who identified the activity of the Tanzanian Swedish NGO known as Karibu Tanzania, which had been sponsoring parent students schooling at Njombe Institute of Adult Education. In regards to the payment of school fees, one of the interviewed teenage mothers asserted "I am thankful that the NGO is paying school fees and all other costs related to my study for two years now". The same findings also show that $40 \%$ of the NGOs support teenage mothers through the provision of learning materials. The findings concur with Georgen (2009) who stressed the work of the NGO known as Edukaid that had been providing uniforms to poor girls in Mitindani Mtwara as a means of enabling them to return to school after delivery. When responding about the kind of basic education support given to her daughter, one of the interviewed parents stressed that "there are many things I can mention as supports given by the NGO to my daughter, but the remarkable ones are the materials that have enabled her to get back to school".

Likewise, the findings show that $80 \%$ of the NGOs engages in sensitisation and counselling of the girls, parents and guardians as well as community members about different alternative pathways through which teenage mothers can access and complete basic education out of the public school system. Such alternative pathways include private schools, tuition centres and private candidacy, among others. On that same note, Mushi (2009) asserted that NGOs in Tanzania had implemented sensitisation and counselling activities as a means of supporting teenage mothers to resume studies after delivery. The findings revealed that sensitisation is regarded as a primary activity in basic education support to teenage mothers by about $80 \%$ of the NGOs. On the other side, nearly $100 \%$ of the interviewed teenage mothers and their parents/guardians testified that they had been reached by the NGOs through sensitisation campaigns.

With regard to the establishment of learning centres, we found out that only $10 \%$ of the NGOs have established and operating training centres that enrol teenage mothers. As depicted by Mushi (2009) that UMATI has remarkably established and operating learning centres that enrol teenage mothers since 1984, the findings evidenced that running of the learning centres such as open schools is done by NGOs in supporting teenage mothers out of the public school system. The enrolled teenage mothers are taught in secondary subjects and then registered as private candidates for qualifying test or form four national examinations. Likewise, the findings correspond to HEART (2015) which reported accelerated learning as the NGOs activity employed in supporting teenage mothers who fail to return to public schools in Kenya. Moreover, as shown in Table 1, about $90 \%$ of the NGOs under this study have been doing fundraising and then allocate the acquired funds in sponsoring teenage mothers. For instance, data from the document reviewed showed that one of the NGOs had been funded by the US NGO known as Firelight Foundation for about five consecutive years. In line with the above findings, UNESCO (2015) has been raising funds and reported to have capacitated about 149 teenage mothers to enrol in non-formal secondary education and evening classes in Shinyanga rural, Kahama and Msalala district in Shinyanga region.

In that same juncture, about $50 \%$ of the NGOs have been partnering with devoted parents and guardians in sharing different costs incurred in sending teenage mothers back to school. Interpretation from this fact indicates that there are some parents and guardians who have realised the importance and responsibility of supporting pregnant school girls to 
get back to school through alternative pathways after delivery. For instance, one of the interviewed parents remarked: "the NGO is paying her school fees, but I cover all other costs for her studies". Likewise, about $30 \%$ of the interviewed teenage mothers revealed that their parents have in one way or another financed their studies in collaboration with the supporting NGOs.

Furthermore, the findings indicated that about $90 \%$ of the NGOs links teenage mothers with other NGOs, especially in a situation when the former cannot directly support them financially or otherwise. Therefore, girls are introduced to other NGOs which have resources and facilities at that particular time. For instance, we realised that the NGO that has a learning centre accepts and enrols clients sent from other NGOs. The findings tend to agree with a response from the interviewed teen mother who asserted that "I was linked to my sponsoring NGO by the other NGO". Also, the findings show that about $30 \%$ of the NGOs do connect teenage mothers with institutions that enrol teenage mothers. From this point of view, it can be construed that there are several institutions which enrol teenage mothers, but such an opportunity is not well known to the public. It is therefore becoming a role of NGOs to link the girls with such institutions. In line with this finding, SRHRA and Rutgers (2016) stressed that some of the pregnant schoolgirls in Tanzania returned to private schools or Institutes of Adult Education after being expelled from public schools.

\section{Effectiveness of the NGOs Activities}

Analysis of the findings under this study has generally indicated that NGOs activities are less effective in supporting and enabling teenage mothers to access and finish basic education out of the public school system. Bearing in mind that teenage mothers have never allowed returning to public schools in Tanzania mainland ever since the finding was made to assess the effectiveness of NGOs activities for a period of five years; from 2014 to 2018. Data in Table 2 shows that for a period of the last five years (2014-2018) out of 1,365 teenage mothers who were identified by NGOs for basic education support, only $108(8 \%)$ were enabled to access secondary education.

Table 2 shows that $39(2.9 \%)$ out of 1,365 completed secondary education under NGOs support. The same figure also shows that about $76 \%$ of the identified teenage mothers ended up sensitised and counselled but did not returned to school. Thus, analysis of the above findings indicates that NGOs activities are less effective to over $97 \%$ in enabling teenage mothers to accomplish basic education out of the public school system. Likewise, the findings show that $100 \%$ of teenage mothers who dropped out of primary schools were not enabled to access primary education within a period of five years. In regards to the current dropout rates in the country, about 8000 girls drop out of primary and secondary schools due to pregnancy every year (Human Rights Watch, 2017). Hence, taking this figure into account, and comparing it with the level of NGOs effectiveness as revealed by the findings of this study, it is therefore evident that NGOs activities are less effective in regards to the number of teenage mothers who need immediate help.

Table 2: Number of Teenage Mothers Identified and Supported through NGOs Activities

\begin{tabular}{lllllll}
\hline Year & $\begin{array}{l}\text { No. of Teenage } \\
\text { Mothers } \\
\text { Identified }\end{array}$ & $\begin{array}{l}\text { Helped } \\
\text { sensitisation } \\
\text { counselling }\end{array}$ & $\begin{array}{r}\text { through } \\
\text { and }\end{array}$ & $\begin{array}{l}\text { Helped to get back } \\
\text { to schools (private, } \\
\text { open, or non- } \\
\text { formal) }\end{array}$ & $\begin{array}{l}\text { Completed } \\
\text { class VII }\end{array}$ & $\begin{array}{l}\text { Completed } \\
\text { for IV }\end{array}$ \\
\hline $\mathbf{2 0 1 4}$ & 235 & $160(68 \%)$ & $5(2 \%)$ & - & $1(0.4 \%)$ \\
$\mathbf{2 0 1 5}$ & 316 & $311(98 \%)$ & $35(11 \%)$ & - & $2(0.6 \%)$ \\
$\mathbf{2 0 1 6}$ & 274 & $146(53 \%)$ & $5(1.8 \%)$ & - & $4(1.5 \%)$ \\
$\mathbf{2 0 1 7}$ & 293 & $184(63 \%)$ & $22(7.5)$ & - & $29(9.9 \%)$ \\
$\mathbf{2 0 1 8}$ & 247 & $229(93 \%)$ & $41(16.6 \%)$ & - & $3(1.2 \%)$ \\
Total & $\mathbf{1 , 3 6 5}$ & $\mathbf{1 , 0 3 0 ( 7 6 \% )}$ & $\mathbf{1 0 8}(\mathbf{8 \%} \%)$ & - & $\mathbf{3 9 ( 2 . 9 \% )}$ \\
\hline
\end{tabular}


Like Mbugua (2013), the findings indicated that nearly $100 \%$ of NGOs engaged in the provision of basic education support to teenage mothers based in urban areas while the majority of the teenage mothers who are in need of the NGOs support reside in rural areas. Likewise, most of the alternative education centres such as evening classes and tuition centres are found in urban areas where teenage mothers from rural areas cannot access them easily. In this regard, the observed ineffectiveness might in one way or another be contributed by NGOs' concentration in urban areas.

Unfortunately, the findings in this study, other NGOs activities apart from paying school fees have to a very low extent enabled teenage mothers in accessing and completing basic education out of the public school system. For instance, the findings show that out of 1,030 teenage mothers who were sensitised from 2014 to 2018 only 108 (11\%) managed to get back to school with about $39(2.9 \%)$ completed form four by the end of 2018. The fact is that parents and community members have not been well sensitised to a level of eradicating stigma over teenage mothers and assume full responsibility is supporting them through alternative education pathways. In emphasising his reluctance in supporting her daughter one of the parents said: "I thank the NGO for sensitising us about the alternative ways of sending her back to school, but I can't support her anymore because I am feeding her and her baby". Evidently, a statement such as this shows that some of the parents have not yet realised the importance and responsibility of supporting their girls who have dropped out of schools due to pregnancy. Besides, about $90 \%$ of interviewed teenage mothers expressed the conviction that families are not well sensitised as they have been very irresponsible in supporting education for teenage mothers. One of the interviewed teenage mothers expressed her grief by saying "I asked my brother to support me, but he told me to find the father of my child for help".

On the other side, we found through document review that about $80 \%$ of the NGOs have multiple goals hence supporting teenage mothers is not taken as their core thematic goal. Only $20 \%$ have specifically specialised in supporting teenage mothers as their central mission. Likewise, we found out that about $90 \%$ of the NGOs have no specific budget for supporting teenage mothers or any strategic plan for basic education support to teenage mothers. Most of their activities and financial reports, as well as management minutes and resolutions, are prepared by combining multiple goals. In this regard, less attention and commitment has been paid to providing basic education support to teenage mothers compared to the number of teenage mothers who are in need of NGOs' help.

\section{NGOs Ability in Maintaining Continuity of Basic Education Support to Teenage Mothers}

Analysis of the findings on the question of NGOs' ability in maintaining continuity of basic education support to teenage mothers indicated that over $70 \%$ of the NGOs have weaker ability based on their current commitments, resources and plans as presented in figure 3 below. Key indicators on the sustainability of the NGOs services such as availability of a strategic plan showed that only $30 \%$ of the NGOs have defined and well documented future plans concerning the ways and resources through which they will execute their activities and provide support to teenage mothers. In addition to that, we also find that almost all NGOs have no specific plans and strategies for sustaining their general activities and existence. Very unfortunately, the findings showed that only $10 \%$ of the NGOs have designed and implemented resource mobilisation plans that are specific for teenage mothers' basic education support. Likewise, the findings from the document review showed that only $10 \%$ of the NGOs have reliable sources of funds that were enough in financing activities related to basic education support to teenage mothers for a period of one year ahead. However, the findings indicated that almost all NGOs (100\%) had approved constitutions and legal status, only $50 \%$ have a capacity of complying with the NGOs Act and regulations by paying the annual fee. This situation indicates that $50 \%$ of the NGOs involved in this study are in danger of their registration being cancelled at any time due to failure in paying the annual fee. 
Table 3: Indicators of NGOs' Sustainability in the Provision of Basic Education Support to Teenage Mothers

\begin{tabular}{lll}
\hline Indicators for sustainable basic education & Yes & No \\
\hline Valid constitution for girls support & $10(100 \%)$ & $-(0 \%)$ \\
Registration as NGOs & $10(100 \%)$ & $-(0 \%)$ \\
Compliance with the NGOs Act & $5(50 \%)$ & $5(50 \%)$ \\
Strategic plan in place & $3(30 \%)$ & $7(70 \%)$ \\
Resources mobilization plan in place & $1(10 \%)$ & $9(90 \%)$ \\
Activities and organization sustainability plan & $-(0 \%)$ & $10(100 \%)$ \\
\hline
\end{tabular}

However, the findings have shown less involvement of the community and other stakeholders in the plans of the NGOs in such a way that endangering their sustainability because, in turn, NGOs are likely to receive less community support in the future. Data from documents review showed that about $100 \%$ of the NGOs had adopted the traditional paradigm of a top-down approach in planning, implementing, monitoring and evaluating their activities. On that same note, Silk (2015) reported uncertain sustainability of NGOs activities due to the use of the same approach in most of their activities. Poor community involvement, in this case, has some repercussions in the implementation of the NGOs' interventions, especially when their activities yield poor results due to irrelevant or wrong approaches in addressing community problems. In the expression of her aspiration in the continuity of NGOs activities, one of the interviewed parents asserted "before they helped my daughter I was not aware if NGOs were working in a committed way like that". Hence, regardless of the expressed desire and wishes of the helped teenage mothers and their parents to see continuity and expansion of the NGOs activities, poor involvement of beneficiaries in planning signalised small ability to maintain effective continuity.

\section{CONCLUSION AND RECOMMENDATIONS}

It is well known that the responsibility of supporting teenage mothers to accomplish basic education out of the public school system in Tanzania has largely been left into the hands of NGOs. Instantaneously, several NGOs have designed and implemented various activities such as awareness-raising, sponsorship, provision of learning materials, establishment and operation of learning centres as well as partnering with parents and linking of teenage mothers with other potential supporters.
However, with regards to the ever-increasing number of teenage mothers and comparing to the ineffectiveness of NGOs support as has been realised in this study, we can conclude that over $97 \%$ of the teenage mothers remain completely unassisted. That is to say, the current number of NGOs, their capacity, commitment, strategies, resources and nature of activities are generally ineffective in bearing the entire responsibility of supporting and enabling teenage mothers to accomplish basic education out of the public school system. By considering the importance of educating teenage mothers who dropped out of primary and secondary schools before they have taken basic education qualifications, the recommendation is made to the devoted NGOs that they should take this philanthropic obligation more seriously as their core goal instead of taking it partially. In reality, the current situation dictates for serious engagement of NGOs because in most cases, teenage mothers do lack effective support from other key stakeholders because of their restrictive standpoints and moral claims. On that same note, the appeal is made to the government of Tanzania that as the chief human rights stakeholder and promoter, she should make a right to education a reality to all. She must review her current policy and come up with a more helpful approach to responding to the problem; enabling teenage mothers to accomplish basic education under a well-structured public-funded system. It must, therefore, be known that the exclusion of teenage mothers entrenches the vicious cycle of poverty by creating ignorant and poor mothers in the country. Thus, in a country where ignorance is regarded as one of the enemies of the nation; policies, laws and practices should not leave any citizen behind in all levels of education. 


\section{REFERENCES}

Aglionby, J. (2017, October 17). Tanzania's enemies of the state: Pregnant young women. Retrieved on September 18, 2018, from Financial Times, https://www.ft.com/content/c7 507730-712c-11e7-93ff-99f383b09ff9

Akunga, A. (2008). Promoting girls' education: The experience in Nigeria. Nigeria: United Nation Girls Education Initiative.

Clark, C. (1996). UNICEF for beginners. New York, USA: Writers and Readers Publishing, Inc.

EQUIP - Tanzania. (2017). Annual Summary 2016 - 2017: Improving Learning Outcomes, Particularly for Girls. Tanzania: EQUIP

Georgen, R. (2009). PASHA's contribution to addressing teenage pregnancies in schools in Tanzania. Basel, Switzerland: Swiss Centre for International Health

Haule, G., \& Hombo, E. (2017, June 23). JPM: Wanafunzi wanaopata mimba marufuku kurudi shuleni. Retrieved on September 18, 2018, Mtanzania Digital from https://mtanzania.co.tz/j pm-wanafunzi-wanaopata-mimba-marufukukurudi-shuleni/

HEART. (2015). Education for pregnant girls and young mothers. Retrieved on February 27, 2019 from https://www.heart-resources.org/wpcontent/uploads/2015/11/Education-pregnancyand-young-mothers-kenya-nigeria-UK-africa2.pdf

Issah, H. (2012). The role of Non-Governmental Organisations in girl-child education in the Tolon-Kumbungu District of the Northern Region of Ghana (Doctoral dissertation). Kwame Nkrumah University of Science and Technology.

Jivani, R. (2010). What are the Impacts of NonGovernmental Organisations on the Lives of the Citizens of Tanzania? University of Pennsylvania.

Kiondo, A., Wallevik, H., \& Lange, S. (200). Civil Society in Tanzania. Chr. Michelsen Institute.
Kisanji, J. (2009). CSOs' performance in education development in Tanzania. Presentation for the Education Sector Review 2009, Waterfront NSSF Building, Dar es Salaam.

Kiseu, G. W. (2012). Non-Governmental Organisations' Educational Contribution to Needy Primary School Children in Voi Division, Kenya. MED Thesis, Kenyatta University, Kenya.

Lwiza, F. L. (2014). An investigation into the reentry of learners with disabilities in selected schools in Lusaka province, Zambia. Master's Thesis. University of Zambia Lusaka.

Mbugua, N. W. (2015). Stakeholders' Roles in Implementing the Readmission Policy on Adolescent Mothers in Public Secondary Schools in Kikuyu District, Kiambu County, Kenya. Doctoral dissertation, Catholic University Of Eastern Africa.

Mushi, P. A. K. (2009). History and development of education in Tanzania. Dar es Salaam, Tanzania: Dar es Salaam University Press.

Niskanen, I. (2012). Paying the price of pregnancyYoung mothers' educational prospects in Tanzania. Retrieved December 20, 2018 from http://www.sh.se/p3/ext/res.nsf/vRes/inst f_naturvetenskap_miljooch_teknik_1371 12537 8756_exempel6_pdf/\$File/Exempel6.pdf

Omwancha, K. M. (2012). The implementation of an educational re-entry policy for girls after teenage pregnancy: A case study of public secondary schools in the Kuria District, Kenya. Doctoral Thesis, Victoria University of Wellington.

Rose, P. (2009). NGO provision of basic education: alternative or complementary service delivery to support access to the excluded? Compare, 39(2), 219-233.

Shivji, I. G. (2004). Reflections on NGOs in Tanzania: what we are, what we are not, and what we ought to be. Development in Practice, 14(5), 689-695.

Sik, I. (2015). Early Motherhood in Tanzania: Exploring the Education, Health and 
Employment Challenges of Dar es Salaam's Adolescent Mothers. Honours dissertation, University of Toronto, Scarborough.

SRHRA \& Rutgers. (2016). The Right to Education of Pregnant Girls and Young Mothers: TANZANIA. Tanzania Sexual and Reproductive Health and Rights Alliance (SRHRA) \& Rutgers. Retrieved December 18, 2018, from https://www.rutgers.international/sites/rutgersor g/files/PDF/Advocacy_Tanzania_0.pdf

Swainson, N., Bendera, S., Gordon, R., \& Kadzamira, E. (1998). Promoting Girls' Education in Africa: The Design and Implementation of Policy Interventions. Education Research Paper. London United Kingdom: Department for International Development, Education Division.

Tanzania Sexual and Reproductive Health and Rights. (2016). The right to education of pregnant girls and young mothers. Retrieved June 12, 2018, from https://www.rutgers.interna tional/sites/rutgersorg/files/PDF/Advocacy_Tan zania_0.pdf

Tripp, A. M. (2000). Political Reform in Tanzania: The struggle for association autonomy. Retrieved June 06, 2018 from https://ecpr.eu/fil estore/paperproposal/5451e271-784f-4f899895-3d0dc2da3664.pdf

UNESCO. (2015). Good Practices Tanzania Providing alternative learning for adolescent mothers: UNESCO

UNICEF. (2003). Girls' Education in Tanzania. Tanzania: UNICEF

United Republic of Tanzania (URT). (2017). National survey on the drivers and consequences of child marriage in Tanzania. Dar es Salaam, Tanzania: United Republic of Tanzania.

Winthrop, R. \& King, E. (2015). Today's challenges for girls' education. Brookings Global Working Paper Series.

World Health Organization. (2014). Global Status Report on Violence Prevention 2014. Retrieved June 6, 2018 from https://apps.who.int/iris/rest/ bitstreams/649376/retrieve 